\title{
IDENTIFIKASI AWAL DAN REKONSTRUKSI ASPEK BIOLOGIS TEMUAN RANGKA MANUSIA LJ-1 SITUS LEANG JARIE, MAROS, SULAWESI SELATAN
}

\section{Identification and Biological Aspects Reconstruction of Human Remains LJ1 Leang Jarie, Maros, South Sulawesi}

\author{
Fakhri $^{1 \mathrm{a}}$, Budianto Hakim ${ }^{\text {1b }}$ \\ ${ }^{1}$ Balai Arkeologi Sulawesi Selatan \\ Jl. Pajjaiyang No. 13 Sudiang Raya Makassar, Indonesia \\ afakhri@kemdikbud.go.id \\ bbudianto.hakim@kemdikbud.go.id
}

Naskah diterima: 04/09/2019; direvisi: 30/10-27/11/2019; disetujui: 28/11/2019

Publikasi ejurnal: 28/11/2019

\begin{abstract}
The purpose of this study is to provide an explanation of the physical aspect reconstruction effort one of the human skeletal findings that once bathed the Maros karst area. The results of excavations in 2018 and 2019 found a human skeleton at the Leang Jarie Site (LJ-1) associated with the Toalian techonology stone tools and Austronesian earthenware, with age 2700 BP. Morphometric analysis of the LJ-1 framework on the skeletal part that remains and can be recognized, known that the sex is a male aged 35-40 years with a height of $166 \mathrm{~cm}$, originating from the Austronetian nation. This framework is considered as important data and evidence of human presence as ancestors of the inhabitants of the Maros cultural region, which provides evidence of the relationship between the Austromelanes race (the Toalian people) and the Mongoloid race (Austronesian people). the technology found in one context with this framework is bone artifacts in the form of Bone point, Maros point, mollusca shell kitchen waste and some pottery fragments. The results of this study can provide a new perspective on racial interactions (Austromelanesoid with Austronesian) in the past.
\end{abstract}

Keyword: Toalian, Leang Jarie, skeleton LJ-1, Maros point.

\begin{abstract}
Abstrak
Penelitian ini menggunakan teknik survei dan observasi, dengan metode deskriptif dan penalaran induktif. Tujuan penelitian ini adalah untuk memberi penjelasan tentang usaha rekonstruksi aspek fisik salah satu temuan rangka manusia yang pernah mendiami kawasan karst Maros. Hasil ekskavasi tahun 2018 dan 2019 menemukan rangka manusia di Situs Leang Jarie (LJ-1) berasosiasi dengan alat batu teknologi Toalian dan gerabah Austronesia, dengan umur 2700 BP. Analisis morfometri terhadap rangka LJ-1 pada bagian rangka yang masih tersisa dan dapat dikenali, diketahu bahwa berjenis kelamin adalah laki-laki, berusia 35-40 tahun dengan tinggi badan $166 \mathrm{~cm}$, berasal dari bangsa Austronesia. Rangka ini dianggap sebagai data dan bukti penting kehadiran manusia sebagai leluhur penghuni wilayah budaya Maros, yang memberikan bukti terjadinya relasi antara ras Austromelanesoid (bangsa Toalian) dengan ras Mongoloid (bangsa Austronesia). Adapun teknologi yang ditemukan dalam satu konteks dengan rangka ini adalah artefak tulang berupa lancipan (bone point), artefak batu (maros point), sampah dapur cangkang moluska dan beberapa fragmen tembikar. Hasl penelitian ini dapat memberikan perspektif barun tentang intereaksi antara ras (Austromelanesoid dengan Austronesia) yang melahirkan suatu bentuk akulturasi buadaya yang terjadi pada masa lampau.
\end{abstract}

Kata Kunci:. Toalian, Leang Jarie, rangka LJ-1, Maros Point. 


\section{PENDAHULUAN}

Pengumpulan data dan survei di wilayah kars Maros ini telah dilakukan sejak masa kolonial Belanda. Beberapa peneliti asing telah membuka wawasan dan tabir baru tentang kehidupan prasejarah di kawasan Maros - Pangkep atau di kawasan budaya Toala (Suryatman et al., 2019). Sejak Paul dan Fritz Sarasin berkunjung pada 1902, penelitian lanjutan di kawasan ini dilakukan oleh van Stein Callenfels, Noone, Cense, Willems, Mc Carthy, dan Heekeren. Hingga pada 1937 kembali Callenfels melakukan penelitian pada gua yang pernah diteliti oleh Sarasin bersaudara (Tanudirjo, 2005). Pada 1969, penelitian terhadap gua prasejarah di Sulawesi Selatan semakin banyak dikaji, terbukti adanya penelitian kerjasama antara Indonesia dan Australia yang dipimpin oleh Soejono dan Mulvenay. Penelitian tersebut menitikberatkan pada pertanggalan yang lebih akurat. Penelitian ini dilakukan pada beberapa gua, antara lain Batu Ejaya (Bantaeng), Leang Burung dan Ulu Leang (Maros). Menurut Glover bahwa sesuai analisis C14 yang diterapkan pada sampel Gua Ulu Leang, diketahui tahapan penghunian manusia adalah berkisar antara 10500 sampai 3500 BP (Duli, 1992; Poesponegoro \& Notosusanto, 1984).

Beberapa ekskavasi pada lapisan budaya Pleistosen akhir juga pernah dilaporkan dari Situs Leang Burung 2 dan Leang Sakapao. Di Situs Leang Burung 2, lapisan budaya diperkirakan berumur 29,000 hingga 19,000 tahun lalu berkonteks dengan artefak batu diserpih (Glover, 1981; Sinha \& Glover, 1984). Sedangkan untuk Situs Leang Sakapao 1 (Pangkep) menunjukkan pertanggalan antara 30,000 hingga 20,000 tahun yang lalu juga berkonteks dengan himpunan artefak batu diserpih (Bulbeck, Sumantri, \& Hiscock, 2004). Hingga 2014, bukti budaya tertua yang dilengkapi dengan data pertanggalan adalah dating dari tradisi gambar cadas yang ditemukan pada dindingdinding gua. Hasil pertanggalan menggunakan metode Uranium Series di beberapa gua menunjukkan kisaran umur 40,000 hingga 18,000 tahun yang lalu (Aubert et al., 2014).

Hasil penelitian tentang gua-gua di kawasan Asia Tenggara (Ismail, Ramli, Supian, Hussin, \& Duli, 2018) termasuk gua-gua di Sulawesi Selatan membuktikan bahwa sejak jaman Plestosen akhir, gua-gua telah dihuni (Duli, Mulyadi, \& Rosmawati, 2019; Duli \& Nur, 2016), berlangsung terus hingga jaman Neolitik, bahkan gua-gua digunakan sebagai tempat beraktivitas termasuk sebagai tempat penguburan sampai pada jaman sejarah dan etnografi (Duli, 2013, 2014, 2015).

Bahan kajian dalam artikel ini adalah data penelitian dari ekskavasi Balai Arkeologi Sulawesi Selatan yang secara intens telah dilakukan sejak 2018 (Hakim et al., 2018). Penelitian ini dipimpin oleh Budianto Hakim dengan melakukan eksplorasi berupa survei dan ekskavasi situs gua prasejarah di sepanjang kawasan karst Maros Pangkep. Salah satu situs yang menjadi pusat perhatian dalam ekskavasi adalah situs gua prasejarah Leang Jarie. Secara administratif situs ini terletak di Desa Samanggi, Kecamatan Simbang, Kabupaten Maros. Adapun secara astronomis situs ini berada pada titik $5^{\circ} 2^{\prime}$ 07.7' LS dan $119^{\circ} 44^{\prime}$ 33.1" BT dengan ketinggian 102 mdpl. Situs ini adalah salah satu situs cagar budaya yang pernah dijadikan sampel pertanggalan untuk umur gambar cadas yang tersebar di wilayah Karts Maros dengan kisaran umur antara 40,000 hingga 18,000 BP (Aubert et al., 2014).

Berdasarkan pengamatan yang dilakukan, situs ini memiliki potensi arkeologi berupa sisa pemukiman masa prasejarah. Indikasi temuan berupa artefak alat serpih dan konkresi sisa makanan berupa cangkang moluska tersebar merata di permukaan situs. Situs ini disurvei oleh Budianto Hakim pada 2017 dengan penemuan berupa rahang dan gigi manusia di lantai permukaan gua. Dari survei 
tersebut, observasi kemudian ditindaklanjuti dengan ekskavasi di Situs Leang Jarie. Dugaan kehadiran rangka manusia di situs ini dikuatkan dengan adanya temuan gigi manusia dari Situs Leang Jarie. Temuan ini tersingkap pada permukaan gua berasosiasi dengan temuan arkeologis lainnya antara lain alat batu, tembikar, tulang dan kerang (Hakim, 2017).

Berdasarkan beberapa rangkaian penelitian yang telah dilakukan, belum ada yang memberikan data berupa kehadiran rangka manusia sebagai bagian dari konteks budaya prasejarah. Data kehadiran manusia pada konteks situs prasejarah dengan didukung data pertanggalan dianggap penting untuk menjelaskan tentang ras manusia yang menghuni kawasan ini. Dengan ketersediaan data rekonstruksi rangka manusia dari Situs Leang Jarie akan dapat mengisi kekosongan data khususnya penjelasan tentang ciri fisik dan beberapa rekonstruksi aspek biologis manusia sebagai bagian dari sejarah penghunian di Leang Jarie pada masa 2700 BP.

Rentang waktu pada masa 2700 tahun telah diketahui sebagai bagian dari masa penghunian Austronesia di Sulawesi (Simanjuntak, 2008). Informasi ini nampaknya dapat menjadi bagian penting atau sebagai bahan pembanding dalam penelitian ini untuk tidak secara mudah menjustifikasi rangka manusia di Leang Jarie sebagai manusia prasejarah yang telah berusia lebih dari masa 3000 tahun yang lampau atau bahkan dengan mudah menyatakannya sebagai manusia dengan ciri Austromelanesid. Untuk menjawab permasalahan ini, nampaknya penelitian ini memiliki posisi yang penting untuk mengisi gap research khususnya terkait dengan identifikasi awal dan rekonstruksi biologis temuan rangka manusia LJ-1 di Maros, Sulawesi Selatan.

Salah satu tujuan yang dicapai dari penelitian ini adalah penjelasan secara umum tentang ciri fisik manusia dari hasil ekskavasi berupa temuan rangka pada Situs
Leang Jarie dalam kronologi lapisan budaya masa $2750 \mathrm{BP}$ yang pernah ditemukan di Sulawesi Selatan. Oleh karena itu, untuk menghindari pembahasan yang lebih jauh, dalam artikel ini kami membatasi permasalahan yaitu pada uraian ciri anatomis yang dapat diidentifikasi pada sisa rangka manusia LJ-1 di Maros dengan harapan tentunya tidak terlepas dari tujuan penelitian yang dilakukan. Dari indikasi temuan awal ini, kemudian diputuskan untuk melakukan eksplorasi arkeologi secara sistematis berupa ekskavasi.

Penggalian dimulai dengan membuka kotak gali S1B2, S1B1, S2B2, S2B1 dan S2T1 untuk menampakkan secara utuh rangka manusia yang terdapat pada situs tersebut. Tujuan penulisan artikel ini diarahkan pada perumusan masalah yang lebih mengarah pada usaha deskripsi terhadap manusia pendukung kebudayaan di wilayah budaya Maros, Sulawesi Selatan. Hal ini didasari pada uraian tentang ciri fisik dan antrofomorfis dari temuan rangka manusia pada situs prasejarah seringkali diabaikan dengan alasan kurangnya tenaga ahli yang dapat menjelaskan tentang rangka yang ditemukan pada setiap penggalian arkeologi. Melalui artikel ini, penulis mencoba menguraikan tentang ciri fisik dari temuan rangka tersebut.

Penemuan rangka manusia dari konteks situs prasejarah yang memiliki kesamaan bentuk budaya dari masa holosen akhir, sebenarnya telah dipublikasikan oleh Fakhri dari Situs Balang Matti di kawasan kars Bontocani, Bone (Fakhri, 2017). Hanya saja, penanganan dan identifikasi awal yang dilakukan belum menggunakan sistem pengukuran morfometri dan identifikasi bagian perbagian dari rangka yang ditemukan. Berbeda dengan penelitian sebelumnya, di Situs Leang Jarie ini dihasilkan data baru yang dapat menjadi referensi kehadiran manusia prasejarah Sulawesi pada masa Holosen awal. Hasil penelitian ini dapat dianggap penting untuk kajian manusia prasejarah di Sulawesi yang 
dapat menggambarkan tentang ciri fisik manusia sapiens yang hadir sejak masa Holosen awal dan telah mengokupasi daerah kars Maros Pangkep pada masa 2700 tahun yang lalu (Hakim et al., 2018).

Beranjak dari data yang tersedia selama penggalian dilakukan, penulis mencoba merumuskan pertanyaan penelitian antara lain:

1. Komponen apa saja secara anatomis tersisa dari temuan rangka manusia $\mathrm{LJ}$ 1 ?

2. Bagaimana identifikasi awal untuk jenis kelamin, usia, tinggi badan termasuk ciri ras yang dimiliki oleh rangka manusia LJ-1?

Untuk menjawab pertanyaan ini, data yang dibutuhkan untuk diuraikan secara biologis dan antropomorfis dapat dilakukan, mengingat ketersediaan data berupa rangka manusia utuh dan ditemukan secara insitu pada matriks dan konteks arkeologisnya di Situs Leang Jarie.

\section{METODE PENELITIAN}

Analisis terhadap rangka manusia Leang Jarie ini menggunakan teknik analisis ekofak sisa manusia yang dirumuskan oleh Widianto dalam bentuk struktur database dengan beberapa penambahan variabel analisis untuk melengkapi uraian data rangka yang ditemukan, sehingga memudahkan bagi penulis untuk pencapaian interpretasi. Adapun struktur data yang laiknya dilengkapi dalam analisis rangka antara lain komponen anatomis tersisa, identifikasi jenis kelamin, identifikasi usia individu dan penentuan jenis ras (Widianto, 2005). Langkah analisis yang digunakan dalam penelitian ini mengacu pada standar analisis terhadap rangka manusia yang telah panjang lebar diuraikan oleh White dan Folkens dalam bukunya tentang proses identifikasi tulang manusia yang seringkali digunakan oleh para ilmuwan dan arkeologi. Dalam uraiannya dijelaskan bahwa penanganan terhadap rangka manusia dilakukan secara teliti tanpa mengabaikan kesalahan sekecil apapun. Dalam memberikan uraian terhadap temuan rangka manusia, diperlukan menentukan umur, menentukan jenis kelamin, menentukan perawakan dan tinggi badan, menentukan DNA, bahkan pada proses identifikasi model penguburan dan apa yang terjadi pada rangka selama kehidupannya termasuk penyakit yang diderita dan fisiologi tubuh secara umum (White \& Folkens, 2005).

Untuk melakukan analisis temuan rangka manusia, maka akan dibutuhkan langkah analisis paleontropologis. Langkah ini merupakan standar analisis yang dibutuhkan dalam memeriksa dan mengidentifikasi bagian-bagian dari rangka manusia yang masih tersisa. Dalam analisis paleontropologis akan dibutuhkan:

1. Analisis Sisa Manusia;

2. Identifikasi Jenis Kelamin;

3. Identifikasi Usia Individu;

4. Identifikasi Jenis Ras; dan

5. Estimasi Tinggi Badan

Beberapa bagian dari analisis paleontropologis ini memudahkan dalam menentukan jenis manusia yang ditemukan dalam suatu penggalian arkeologi (Simanjuntak, 2008). Melihat kondisi temuan Rangka LJ-1 yang sangat memungkinkan untuk dianalisis secara paleontropologis, maka dalam penelitian ini pun akan menggunakan metode analisis yang umum dipakai dalam setiap temuan rangka manusia. Pada analisis yang diterapkan, metode yang digunakan untuk menganalisis komponen anatomis tersisa adalah studi komparasi tulang manusia dengan sisa tulang yang ditemukan pada kotak gali. Demikian pula dengan usaha penentuan jenis kelamin masih dilakukan secara umum, mengingat observasi yang dilakukan terbatas pada permukaan tulang yang tampak di permukaan tanah, tanpa dilakukan pengangkatan terhadap rangka yang dianalisis. Penentuan usia individu dilakukan dengan melihat atrisi dan erupsi pada gigi serta beberapa penyatuan bagian tulang yang masih dapat diamati. Sedangkan 


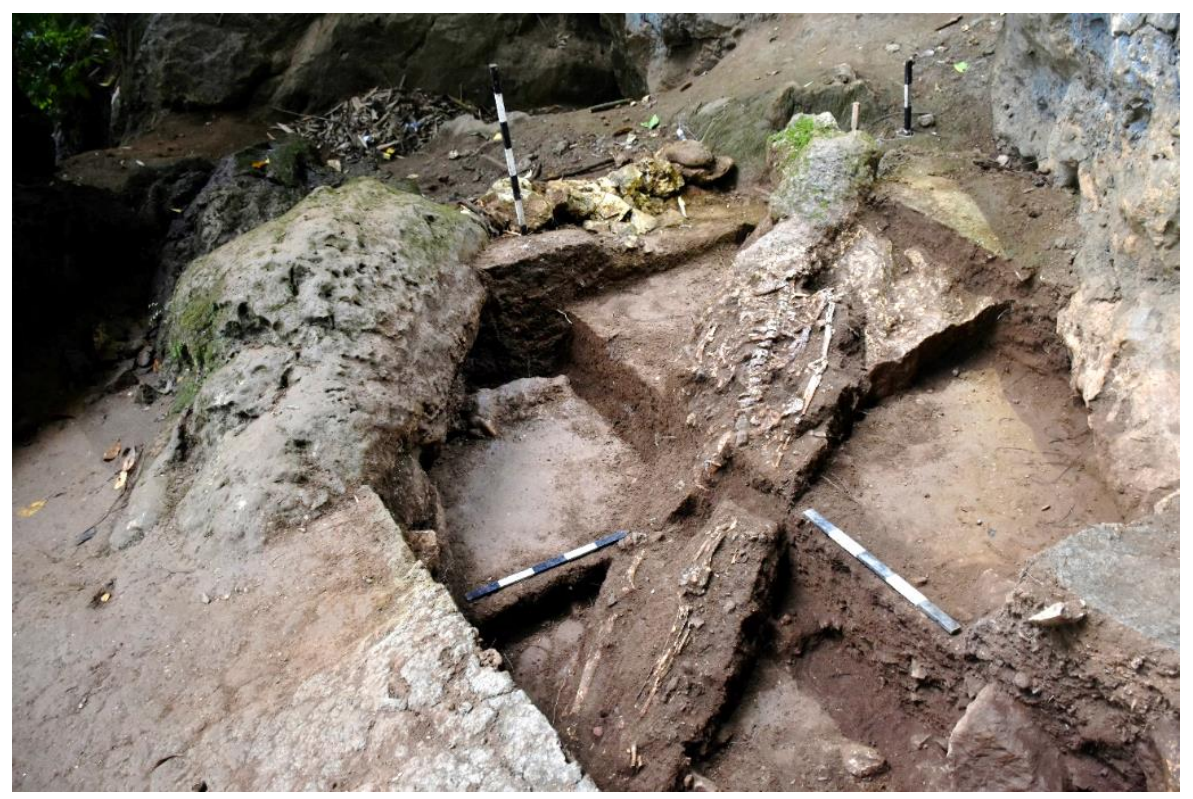

Gambar 1. Rangka Manusia Leang Jarie 1 dengan posisi terlentang (Sumber: Dokumentasi Balar Sul-Sel, Tahun 2018)

untuk penentuan tinggi badan, dilakukan dengan menggunakan formula yang umum digunakan dalam studi osteologi dan forensik.

\section{HASIL DAN PEMBAHASAN}

Pada penggalian Situs Leang Jarie, sampai pada kedalaman $10 \mathrm{~cm}$ dari permukaan tanah di kotak S1B2 tersingkap sisa rangka yang tertanam di pelataran gua. Penggalian kemudian dilanjutkan dengan tujuan pencarian sambungan dan orientasi rangka pada permukaan tanah. Setelah tersingkap, Rangka Manusia Leang Jarie 1 ditemukan pada kotak gali S1B2, S1B1, S2B2 dan S2B1 dan ditemukan dalam satu konteks (gambar 1). Temuan sisa rangka ini ditemukan dalam kondisi sangat rapuh dan terpisah bagian perbagian. Karena kondisi rangka yang sangat fragmentaris, menyebabkan upaya pengangkatan rangka sangat sulit untuk dilakukan. Demikian juga dengan usaha untuk mengukur rangka dalam metric insitu dan pengamatan terhadap epiphysis sangat tidak memungkinkan untuk dilakukan dengan kondisi rangka yang sangat fragmentaris. Temuan rangka LJ-1 ditemukan dalam konteks penguburan primer lurus terlentang dengan orientasi rangka Barat Laut (BL) - Tenggara (TG), superior berada pada bagian BL dan inferior pada bagian TG. Kondisi upper limb dan lower limb membujur ke arah inferior. Posisi metapodial pada carpals nampaknya ditempatkan di atas oscoxae tanpa membentuk orientasi apapun. Adapun temuan arkeologis lainnya yang ditemukan berasosiasi dalam satu lapisan budaya dengan rangka adalah pecahan tembikar, artefak batu serpih bilah dan cangkang kerang. Satu hal yang menarik dari pengamatan terhadap rangka adalah ditemukan 3 buah batuan berukuran 5 sampai $10 \mathrm{~cm}$ di sekitar tulang oscoxae pada bagian pelvis. Jenis batuan adalah 2 buah batuan gamping dan 1 buah batuan sedimen yang terletak tepat di tengah pelvic (gambar 2).

Pengamatan terhadap permukaan lantai situs menunjukkan hal yang menarik. Hal ini disebabkan pada sepanjang bagian kiri, kanan serta bagian superior rangka ditemukan boulder-boulder batu gamping yang mengelilingi rangka. Rangka nampaknya dibaringkan di atas batu dengan 


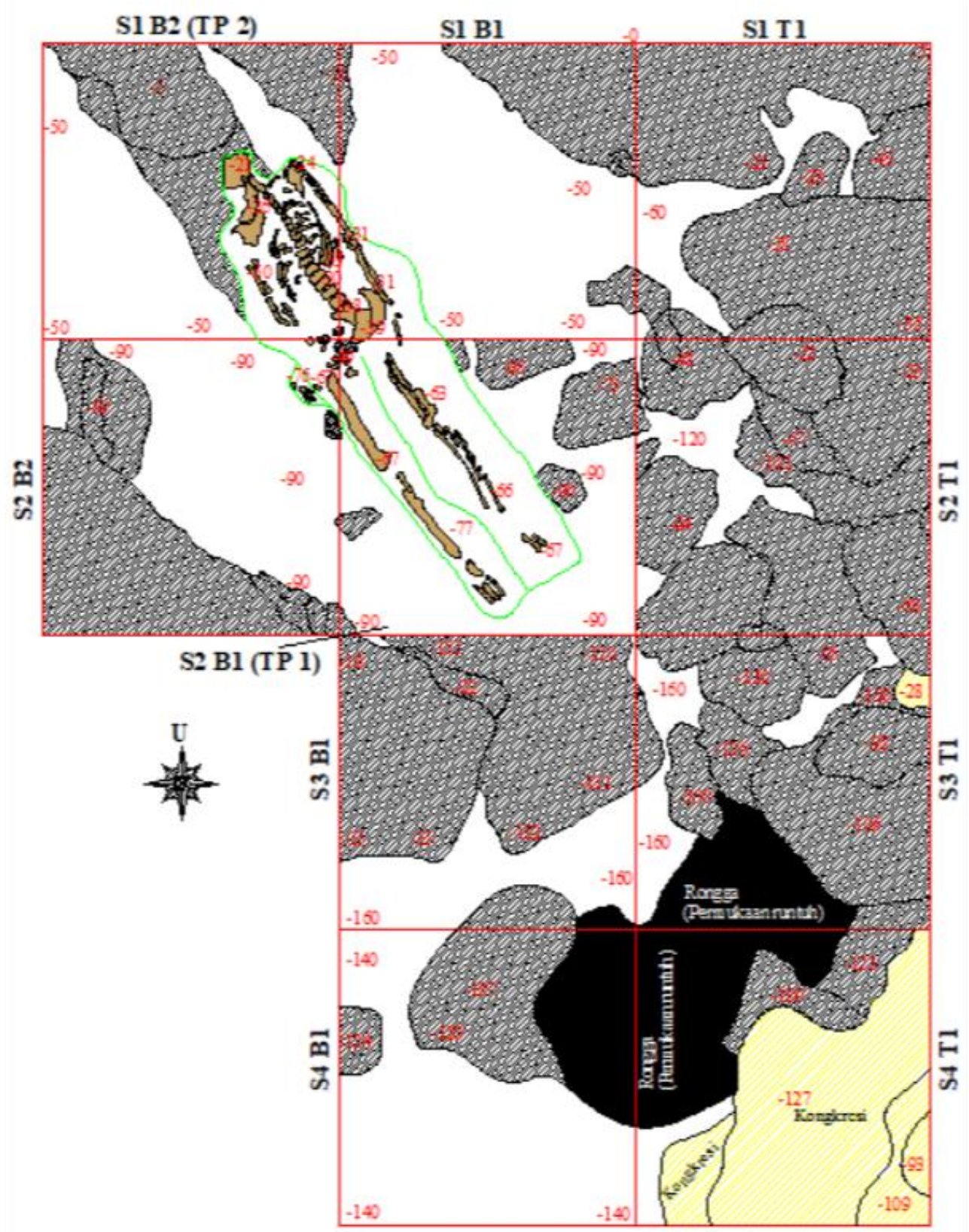

Gambar 2. Posisi rangka Leang Jarie yang dikelilingi oleh batuan gamping (Sumber: Dokumentasi Balar SulSel, Tahun 2019)

posisi cranium (kepala) dan sebagian badan yang bersandar di atas batu (gambar 2).

\section{Komponen Anatomis Tersisa}

Uraian anatomis tersisa dari rangka LJ-1 antara lain dapat dideskripsikan sebagai berikut: pada bagian cranium, sebagian besar tulang telah hancur dan remuk, bahkan telah lapuk dan menjadi bagian dari tanah pengendap. Pada bagian tengkorak, anatomi yang tersisa hanya terdapat pada bagian mandibula sebelah kiri dan dalam kondisi yang rapuh. Kondisi rangka yang sangat rapuh ini menyulitkan bahkan menjadi sesuatu yang tidak mungkin untuk mengidentifikasi kondisi penutupan sutura pada tengkorak. Dalam penentuan estimasi usia rangka salah satunya adalah dapat dilihat dari ketersambungan sutura pada permukaan cranial (White \& Folkens, 2005). Demikian pula dengan usaha identifikasi rangka berhubungan dengan 
jenis kelamin, nampaknya sulit membangun dasar asumsi dari tengkorak, mengingat kondisinya yang sangat fragmentaris. Kondisi fragmentasi cranial ini disebabkan posisi kepala yang terletak sangat dekat dengan permukaan tanah. Proses pelarutan air pada permukaan tanah dan tekanan dari atas permukaan tanah menyebabkan rapuh dan hancurnya cranial pada rangka.

Bagian vertebrae menunjukkan kondisi bagian anatomis yang masih pada posisinya masing-masing. Bagian cervic berjumlah 7, Bagian thoracic berjumlah 12, lumbar berjumlah 5 termasuk masih dapat diamati kehadiran sacrum dan os coxae meskipun dalam kondisi yang sangat rapuh. Masih satu rangkaian dengan vertebrae pada bagian tengah sisi kiri dan kanan rangka, masih ditemukan bagian-bagian tulang rib dalm kondisi yang telah terlepas dari posisinya yang berhubungan dengan vertebra. Sternum sudah tidak ditemukan, meskipun juga masih ditemukan bagian clavicle kiri yang berdekatan dengan scapula kiri. Tulang scapula masih dapat diidentifikasi dan dalam kondisi yang sangat fragmentaris. Temuan scapula masih genap berjumlah 2, meskipun ditemukan dalam kondisi yang sangat rapuh dan memiliki potensi untuk rusak bila proses pengangkatan dilakukan dengan cara yang tidak hati-hati.

Kondisi rangka masih dapat dikenali sampai $70 \%$ lengkap dengan kondisi yang sangat fragmentaris. Bagian upper limb sebelah kiri diidentifikasi sebagai humerus, radius dan ulna, serta beberapa bagian carpals masih dapat dikenali dan diidentifikasi. Upperlimb bagian kanan, hanya ditemukan humerus dalam kondisi yang juga fragmentaris tanpa menyisakan bagian proximal end dan distal end. Materi tersisa dari bagian pelvis antara lain sedikit pada bagian illium sebelah kiri yang tersingkap pada permukaan tanah dan nampaknya tertindih oleh bagian metacarpals kiri dan beberapa bagian phalange. Dari posisi ini, dapat dipastikan bahwa posisi tangan rangka LJ-1 terlentang dan memanjang ke arah inferior rangka. Pemeriksaan rangka selanjutnya adalah pada bagian lower limb. Pada bagian ini anatomis tersisa adalah pada bagian femur distal end di sebelah kiri dan kanan. Lower limb sebelah kiri dapat diidentifikasi sebagai tulang tibia dan fibula yang masih terletak pada posisinya masing-masing. Demikian pula dengan lower limb sebelah kanan dapat diidentifikasi sebagai tibia dan fibula serta beberapa bagian metatarsal dan beberapa bagian phalange. Identifikasi terhadap bagian-bagian ini hanya dapat disebutkan secara umum tanpa menyentuh bagianbagian phalange secara spesifik.

\section{Identifikasi Jenis kelamin}

Identifikiasi terhadap jenis kelamin dilakukan dengan pengamatan pada bagian karakter morfologis pinggul (pelvis). Pada bagian pelvis, menunjukkan bagian pubik yang agak meruncing dan cenderung mengalami penyempitan. Indikasi ini menunjukkan ciri jenis kelamin dari rangka Leang Jarie 1 adalah laki-laki. Meskipun dari pengamatan awal dapat diketahui bahwa rangka LJ-1 adalah laki-laki, namun sangat direkomendasikan untuk melakukan analisis secara lebih cermat terhadap temuan ini. Karena analisis dilakukan hanya dengan mengamati permukaan rangka tanpa mengangkat temuan rangka untuk dianalisis secara lebih akurat. Dalam penelitian ini, disimpulkan bahwa jenis kelamin rangka LJ1 adalah laki-laki.

\section{Identifikasi Usia Individu}

Identifikasi Usia individu menjadi hal yang sangat penting dalam kajian paleoantropologi. Pada usaha untuk menginterpretasi usia individu, White dan Folkens dalam buku Human Bone Manual menyarankan untuk melakukan analisis dengan membuat komparasi antara analisis tulang dan analisis gigi geligi dengan memanfaatkan variabilitas komponen dari satu indikator specimen (White \& Folkens, 
2005). Dari temuan gigi di Situs Leang Jarie, baik dari permukaan dan dari hasil ekskavasi menunjukkan empat komponan yang dapat dianalisis untuk menunjukkan estimasi usia individu. Empat indikator tersebut antara lain: erupsi gigi, atrisi gigi maxilla, atrisi gigi mandibula dan tingkat penyatuan epifisis. Hal lain yang dapat dilakukan adalah pengamatan terhadap tingkat penutupan sutura pada tengkorak, namun dalam kondisi yang sangat hancur dan tidak menyisakan bagian ini, maka sangat tidak memungkinkan untuk melakukan tindakan ini.

1. Erupsi gigi; pada permukaan gigi sangat menunjukkan tingkat erupsi pada stadia tengah yang menunjukkan ciri gigi manusia dewasa tengah yang kemungkinan telah berusia 35 tahun sesuai dengan kriteri yang diajukan oleh (Ubelaker, 2008; White \& Folkens, 2005).

2. Atrisi gigi maxilla berada pada tingkat $\mathrm{G}$, yaitu rentang usia 35 sampai 40 tahun. Pengamatan ini dilakukan pada permukaan cusps gigi yang telah tererosi. Temuan gigi yang ditemukan pada situs Ini adalah pada bagian $\mathrm{M}^{1}$ kanan dan sesuai dengan terminologi Lovejoy (1985) dan White and Folkens (2005).

3. Atrisi gigi mandibula berada pada tingkat $\mathrm{H}$, yaitu rentang usia 40 sampai 45 tahun (Lovejoy, 1985; White \& Folkens, 2005). Pengamatan dilakukan pada permukaan cusps gigi $\mathrm{M}_{2}$ kiri yang tererupsi pada skala tingkat menengah dengan kondisi yang agak rapuh.

4. Tingkat penyatuan epifisis menunjukkan individu situs Leang Jarie adalah manusia dewasa yang telah mengalami penyatuan pada bagian tulang panjang dan memasuki kisaran individu dewasa.

Dari pengamatan terhadap empat indikator tersebut di atas, kami merekomendasikan dan menyimpulkan bahwa rangka manusia LJ- 1 adalah individu yang telah berusia di atas 35 sampai 40 tahun.

\section{Identifikasi Jenis Ras (Ancestry)}

Menyinggung tentang identifikasi rasa di sejumlah situs di nusantara, Widianto menegaskan bahwa hasil penelitian hingga saat ini hanya menunjukkan adanya dua ras pokok yang sering ditemukan dalam konteks sisa rangka prasejarah, yaitu ras Austromelanesid dan ras Mongoloid (Widianto, 2005). Secara umum, identifikasi terhadap ras manusia Leang Jarie 1 menunjukkan ciri ras mongoloid dengan ciri postur tubuh yang tinggi dan lebih kekar. Meskipun tidak ditemukan secara lengkap dari bagian cranial yang dapat menunjukkan ciri secara artikulasi, namun justifikasi terhadap ras mongoloid dapat dilihat dari postur tubuh dan teknologi temuan dengan kurun masa 3000 tahun mencirikan ras manusia mongoloid. Seperti yang telah dijelaskan oleh Widianto (2005) tentang kehadiran jenis ras manusia di Nusantara, disebutkan oleh ras yang ada di Nusantara adalah homo sapiens dan homo erectus. Berdasarkan konteks temuan, maka ras manusia yang ada di Leang Jarie adalah dari ras Mongoloid. Kesimpulan ini didukung dengan kehadiran tembikar yang berasosiasi pada satu lapisan LJ-1 dan demikian pula dengan teknologi artefak batu serpih yang ditemukan di sekitar rangka pada satu lapisan yang mencirikan alat batu neolitik.

\section{Estimasi Tinggi badan}

Melakukan pengukuran terhadap tinggi badan dapat dilakukan dengan menghitung korelasi atau hubungan antara tulang panjang pada satu individu (White \& Folkens, 2005). Pada penelitian yang dilakukan oleh Noerwidi (2012), untuk mengetahui postur tubuh dilakukan pengukuran pada tulang-tulang panjang yang masih terkonservasi dengan baik dengan metode Martin dan Seller. Berdasarkan pada kedua tulang tibia dan fibula yang masih utuh serta sebuah fragmen 
femur kanan, maka dapat diukur panjang maksimal (M1) tulang tersebut. Adapun ketersediaan data pada rangka $\mathrm{LJ} 1$ adalah:

$\begin{array}{ll}\mathrm{H} 1 \rightarrow \text { Humerus }(\mathrm{ki}) & : 33,5 \mathrm{~cm} \\ \mathrm{R} 1 \rightarrow \text { Radius }(\mathrm{ki}) & : 29 \mathrm{~cm} \\ \mathrm{U} 1 \rightarrow \text { Ulna }(\mathrm{ki}) & : 31 \mathrm{~cm} \\ \mathrm{~F} 1 \rightarrow \text { Femur }(\mathrm{ki}) & : 39 \mathrm{~cm} \\ \mathrm{~T} 2 \rightarrow \text { Tibia }(\mathrm{ki}) & : 35 \mathrm{~cm} \\ \text { Fi } 1 \rightarrow \text { Fibula }(\mathrm{ki}) & : 34,5 \mathrm{~cm} \\ \mathrm{~T} 1 \rightarrow \text { Tibia }(\mathrm{ka}) & : 35,5 \mathrm{~cm}\end{array}$

Pada analisis penghitungan tinggi badan ini, kami menggunakan empat jenis acuan formula penghitungan rangka manusia yang sangat umum digunakan para osteolog. Formula ini menggunakan sampel manusia dari jenis ras yang berbeda-beda antara lain, formula untuk laki-laki dewasa eropa, laki-laki kulit hitam, kelompok lakilaki ras mongoloid, dan laki-laki dewasa dari Jawa (Davidson, 2009; Glinka, Artaria, \& Koesbardiati, 2008; Knight, 1996; Kusuma \& Yudianto, 2010; Nandy, 1996).

Dari analisis terhadap tinggi badan dengan menggunakan empat formula yang umum digunakan dalam kajian osteoforensik (lampiran 1) ditemukan bahwa ada beberapa nilai yang menunjukkan angka yang sangat variatif dan berbeda-beda. Sebagai acuan dasar dalam melakukan penentuan ukuran tinggi badan rangka LJ1 maka dilakukan pembagian-jumlah rata-rata ketinggian dari empat formula yang ditawarkan. Dalam analisis ini kami merekomendasikan ukuran tinggi badan manusia $\mathrm{LJ}-1$ adalah 166, $2 \mathrm{~cm}$.

\section{PENUTUP}

Dari uraian terhadap temuan rangka LJ-1 yang ditemukan di situs Gua Leang Jarie, berdasarkan analisis morfometri dapat diketahui bahwa manusia yang hidup pada masa sekitar 2700 BP adalah berjenis kelamin adalah laki-laki, berusia $35-40$ tahun dengan tinggi badan $166 \mathrm{~cm}$. Berdasarkan konteks temuannya dengan gerabah, disimpulkan bahwa rangka LJ-1 tersebut berasal dari ras Mongoloid (bangsa Austronesia) yang masih melanjutkan penggunaaan budaya Toalian.

Temuan budaya pada lapisan rangka LJ-1 menunjukkan adanya akulturasi budaya sebelumnya dengan budaya pendatang (Austronesia), yaitu kehadiran temuan yang berciri budaya Toalian seperti teknologi Maros Point dan lancipan tulang berasosiasi dengan tembikar Austronesia pada satu lapisan budaya dengan temuan rangka manusia LJ-1. Interaksi antara manusia Toalian dengan Austronesia akan menimbulkan banyak pertanyaan dan sangat menarik untuk diteliti pada masa yang akan datang.

\section{UCAPAN TERIMA KASIH}

Penelitian ini tidak dapat terlaksana tanpa bantuan dan perhatian dari beberapa peneliti senior dari Balai Arkeologi Sulawesi Selatan dan Universitas Hasanuddin yang membimbing maupun memberikan saran melalui diskusi dan pengayaan referensi artikel ini. Ucapan terimakasih dan penghargaan penulis berikan kepada Bapak M. Irfan Mahmud selaku kepala Balai Arkeologi Sulawesi Selatan dan Ibu Bernadeta AKW sebagai teman diskusi penulis. Demikian juga kepada Bapak Dr. David Bulbeck dan Delta Bayu Murti yang banyak mengajar penulis tentang dasardasar analisis rangka manusia.

$* * * * * *$

\section{DAFTAR PUSTAKA}

Aubert, M., Brumm, A., Ramli, M., Sutikna, T., Saptomo, E. W., Hakim, B., ... Dosseto, A. (2014). Pleistocene cave art from Sulawesi, Indonesia. Nature, 514, 223-227. https://doi.org/10.1038/nature13422 
Bulbeck, D., Sumantri, I., \& Hiscock, P. (2004). Leang Sakapao 1, a second dated Pleistocene site from South Sulawesi, Indonesia. In S. G. Keates \& J. M. Pasveer (Eds.), Quaternary Research in Indonesia (pp. 111-128). Balkema Publisher.

Davidson, R. J. (2009). Penentuan Tinggi Badan berdasarkan panjang lengan Bawah. Medan: PPDS Forensik Fakultas Kesehatan Universitas Sumatera Utara.

Duli, A. (1992). Adaptasi Manusia Prasejarah pada Gua-Gua di Minasa Tene, Kabupaten Pangkep: Suatu Pendekatan Ekologis. Jurnal Lembaga Penelitian Unhas.

Duli, A. (2013). The Mandu Coffin: A Boat Symbol of Ancestral Spirits Among The Enrekang People of South Sulawesi. Review of Indonesian and Malaysian Affairs, 47(1).

Duli, A. (2014). Shape and Chronology of Wooden Coffins in Mamasa, West Sulawesi Indonesia. Tawarikh, International Journal for Historical Studies, 5(April).

Duli, A. (2015). Typology and Chronology of Erong Wooden Coffins in Tana Toraja, South Celebes. Time and Mind, The Journal of Archaeology, Consciousness and Culture, 8(1), $3-10$.

Duli, A., Mulyadi, Y., \& Rosmawati. (2019). The Mapping Out of Maros-Pangkep Karst Forest as a Cultural Heritage Conservation. In IOP Converence Series: Earth and Environmental Science 270.

Duli, A., \& Nur, M. (2016). Prasejarah Sulawesi. Makassar: FIB Press.

Fakhri. (2017). Indentifikasi rangka manusia Situs Gua Balang Metti, Kabupaten Bone, Sulawesi Selatan. Walennae, 15(2), 89-100.

Glinka, J., Artaria, M. D., \& Koesbardiati. (2008). Metode Pengukuran Manusia. Surabaya: Airlangga University Press.

Glover, I. C. (1981). Leang Burung 2: an upper Paleolthic rock Shelter in South Sulawesi, Indonesia. MQRSEA, 6, 1-38.

Hakim, B. (2017). Interpretasi awal temuan gigi manusia di Situs Bala Metti, Bone dan Situs Leang Jarie, Maros, Sulawesi Selatan. Wa, 15(1), 19-30.

Hakim, B., Mahmud, M. I., Fakhri, Muhaeminah, Herniati, Saiful, A. M., \& Suryatman. (2018). Penelitian Situs Gua Prasejarah di Wilayah Maros dan Pangkep, Sulawesi Selatan. Makassar.

Ismail, N. N. A., Ramli, Z., Supian, N. S. M., Hussin, A., \& Duli, A. (2018). Hoabinhian's lithic technology in Chawan cave, Hulu Kelantan. International Journal of Mechanical Engineering and Technology, 9(13), 1007-1015.

Knight, B. (1996). The Establishment of identity of Human Remains: Forensic Pathology. New York: Oxford University Press.

Kusuma, S. E., \& Yudianto, A. (2010). Identifikasi Medikolegal. In Hoediyanto \& H. Apuranto (Eds.), Ilmu Kedokteran Forensik dan medikolegal (pp. 331-336). Surabaya: Departemen Ilmu Kedokteran Forensik dan Mdekolegal Fakultas Kedokteran Universitas Airlangga.

Lovejoy, C. O. (1985). Dental Wear in the Libben Population: Its Functional Pattern and Role in the Determination of Adult Skeletal Age at Death. American Journal of Physical Antropology, 68, 47-58. 
Nandy, A. (1996). Identification of an Individual: Pronciples of forensic Medicine. Calcutta: New Central book Agency.

Poesponegoro, M. D., \& Notosusanto, N. (1984). Sejarah Nasional Indonesia 1. Balai Pustaka.

S. Noerwidi. (2012). Rekonstruksi Aspek Biologis dan Konteks Budaya rangka Manusia Holosen, Song keplek 5. Berkala Arkeologi, 32(1), 135-150.

Simanjuntak, T. (2008). Austronesian in Sulawesi: Its Origin, Diaspora, and Living Tradition. In Truman Simanjuntak (Ed.), Austronesian in Sulawesi (pp. 215-237). Center for Prehistoric and Austronesian Studies.

Sinha, P., \& Glover, I. C. (1984). Changes in Stone Tool use Southeast Asia 10,000 years Ago. MQRSEA, 8, 137-164.

Suryatman, Hakim, B., Mahmud, M. I., Fakhri, Burhan, B., Oktaviana, A. A., ... Syahdar, F. A. (2019). Artefak Batu Preneolitik Situs Leang Jarie: Bukti Teknologi Maros Point Tertua di Kawasan Budaya Toalean, Sulawesi Selatan. Amerta, 37(1), 1-17. https://doi.org/10.24832/amt.v37i1.1-17

Tanudirjo, D. A. (2005). Theoretical Trends in Indonesia Archaeology. In Theory in Archaeology A World Perspective. London: Taylor and Francis.

Ubelaker, D. H. (2008). Forensic Anthropology: methodology and Diversity of Application. In M. A. Katzenberg \& S. R. Saunders (Eds.), Biological anthropology of the Human Skeletal (pp. 41-70). New Jersey: John Wiley and Sons, inc.

White, T. D., \& Folkens, P. A. (2005). The Human Bone Manual. London: Elsevier Academic Press.

Widianto, H. (2005). Teknik Analisis ekofak: Sisa Mansuia. Jurnal Arkeologi Indonesia, 3, $145-156$. 
Lampiran 1. Hasil analisis tinggi badan menggunakan empat kajian osteoforensis

Tinggi badan berdasarkan formula Karl Pearson untuk laki-laki:

\begin{tabular}{|l|l|l|l|l|l|l|}
\hline Tinggi badan & $\mathbf{1 5 4 . 6 2 6}$ & $=81.306$ & + & 1.88 & $\mathrm{x}$ & $\mathrm{F} 1$ \\
\hline Tinggi badan & $\mathbf{1 6 7 . 5 9}$ & $=70.641$ & + & 2.894 & $\mathrm{x}$ & $\mathrm{H} 1$ \\
\hline Tinggi badan & $\mathbf{1 6 3 . 0 1 2}$ & $=78.664$ & + & 2.376 & $\mathrm{x}$ & $\mathrm{T} 1$ \\
\hline Tinggi badan & $\mathbf{1 8 0 . 7 8 4}$ & $=85.925$ & + & 3.271 & $\mathrm{x}$ & $\mathrm{R} 1$ \\
\hline Tinggi badan & $\mathbf{1 5 7 . 6 1 7 5}$ & $=71.272$ & + & 1.159 & $\mathrm{x}$ & $(\mathrm{F} 1+\mathrm{T} 1)$ \\
\hline Tinggi badan & $\mathbf{7 3 . 1 7 9 0 6}$ & $=71.443$ & + & 1.22 & $\mathrm{x}$ & $(\mathrm{F} 1+1.08 \mathrm{xT} 1)$ \\
\hline Tinggi badan & $\mathbf{1 7 4 . 9 8}$ & $=66.855$ & + & 1.73 & $\mathrm{x}$ & $(\mathrm{H} 1+\mathrm{R} 1)$ \\
\hline Tinggi badan & $\mathbf{1 6 0 . 7 1 7}$ & $=68.397$ & + & $(1.03 \times \mathrm{xF} 1)+(1.557 \mathrm{xH} 1)$ \\
\hline Tinggi badan & $\mathbf{1 5 0 . 6 2 8 9 5 5}$ & $=69.788$ & + & \multicolumn{7}{|l|}{2.769} & $\mathrm{x}$ & $(\mathrm{H} 1+0.195+\mathrm{R} 1)$ \\
\hline Mean : $153.68 \mathrm{~cm}$ &
\end{tabular}

Tinggi badan berdasarkan formula Totter-Glesser (1958) untuk laki-laki ras mongoloid:

\begin{tabular}{|l|l|l|l|l|l|l|l|l|}
\hline Tinggi badan & $\mathbf{1 7 2 . 9 8}$ & $=$ & 2.68 & $\mathrm{x}$ & $\mathrm{H} 1$ & + & 83.2 & \pm 4.3 \\
\hline Tinggi badan & $\mathbf{1 8 4 . 6 6}$ & $=$ & 3.54 & $\mathrm{x}$ & $\mathrm{R} 1$ & + & 82 & \pm 4.6 \\
\hline Tinggi badan & $\mathbf{1 8 5 . 3 8}$ & $=$ & 3.48 & $\mathrm{x}$ & $\mathrm{U} 1$ & + & 77.5 & \pm 4.8 \\
\hline Tinggi badan & $\mathbf{1 5 6 . 4 5}$ & $=$ & 2.15 & $\mathrm{x}$ & $\mathrm{F} 1$ & + & 72.6 & \pm 4.9 \\
\hline Tinggi badan & $\mathbf{1 6 1 . 5 6 5}$ & $=$ & 2.39 & $\mathrm{x}$ & $\mathrm{T} 1$ & + & 81.5 & \pm 3.3 \\
\hline Tinggi badan & $\mathbf{1 6 3 . 4}$ & $=$ & 2.4 & $\mathrm{x}$ & Fi1 & + & 80.6 & \pm 3.2 \\
\hline Tinggi badan & $\mathbf{1 7 9 . 1 7 5}$ & $=$ & 1.67 & $\mathrm{x}$ & (H1+R1) & + & 74.8 & \pm 4.9 \\
\hline Tinggi badan & $\mathbf{1 7 9 . 5 6}$ & $=$ & 1.68 & $\mathrm{x}$ & (H1+U1) & + & 71.2 & \pm 4.10 \\
\hline Tinggi badan & $\mathbf{1 6 1 . 2 9}$ & $=$ & 1.22 & $\mathrm{x}$ & (F1+T1) & + & 70.4 & \pm 4.11 \\
\hline Tinggi badan & $\mathbf{1 5 9 . 8 7}$ & $=$ & 1.22 & $\mathrm{x}$ & (F1+Fi1) & + & 70.2 & \pm 4.12 \\
\hline Mean : $170.43 \mathrm{~cm}$ & & 7 &
\end{tabular}

Tinggi badan berdasarkan formula Antropologi Ragawi UGM untuk laki-laki Jawa:

\begin{tabular}{|l|r|l|r|r|r|l|r|}
\hline Tinggi badan & $\mathbf{1 5 7 5 . 6}$ & $=$ & 897 & + & 1.74 & $\mathrm{x}$ & Femur \\
\hline Tinggi badan & $\mathbf{1 5 6 3}$ & $=$ & 822 & + & 1.9 & $\mathrm{x}$ & Femur \\
\hline Tinggi badan & $\mathbf{1 5 8 9 . 2}$ & $=$ & 879 & + & 2.12 & $\mathrm{x}$ & Tibia \\
\hline Tinggi badan & $\mathbf{1 6 2 4}$ & $=$ & 847 & + & 2.22 & $\mathrm{x}$ & Tibia \\
\hline Tinggi badan & $\mathbf{1 6 2 2 . 5 5}$ & $=$ & 867 & + & 2.19 & $\mathrm{x}$ & Fibula \\
\hline Tinggi badan & $\mathbf{1 6 2 1 . 3}$ & $=$ & 883 & + & 2.14 & $\mathrm{x}$ & Fibula \\
\hline Tinggi badan & $\mathbf{1 7 1 8}$ & $=$ & 847 & + & 2.6 & $\mathrm{x}$ & Humerus \\
\hline Tinggi badan & $\mathbf{1 7 2 2 . 9}$ & $=$ & 805 & + & 2.74 & $\mathrm{x}$ & Humerus \\
\hline Tinggi badan & $\mathbf{1 8 4 2 . 5}$ & $=$ & 842 & + & 3.45 & $\mathrm{x}$ & Radius \\
\hline Tinggi badan & $\mathbf{1 8 4 8}$ & $=$ & 862 & + & 3.4 & $\mathrm{x}$ & Radius \\
\hline Tinggi badan & $\mathbf{1 7 9 5 . 5}$ & $=$ & 819 & + & 3.15 & $\mathrm{x}$ & Ulna \\
\hline Tinggi badan & $\mathbf{1 7 9 5 . 6}$ & $=$ & 847 & + & 3.06 & $\mathrm{x}$ & Ulna \\
\hline Mean: $169.3 \mathrm{~cm}$ & & & & & \\
\hline
\end{tabular}

Tinggi badan berdasarkan formula Stevenson untuk laki-laki:

\begin{tabular}{|l|r|l|l|l|r|r|r|r|r|}
\hline Tinggi badan & 156.7944 & $=$ & 61.7202 & + & 2.4378 & $\mathrm{x}$ & 39 & \pm & 2.1756 \\
\hline Tinggi badan & 175.7504 & $=$ & 81.5115 & + & 2.8131 & $\mathrm{x}$ & 33.5 & \pm & 2.8903 \\
\hline Tinggi badan & 165.1461 & $=$ & 59.2256 & + & 3.0263 & $\mathrm{x}$ & 35 & \pm & 1.8916 \\
\hline Tinggi badan & 188.4412 & $=$ & 80.0276 & + & 3.7384 & $\mathrm{x}$ & 29 & \pm & 2.6791 \\
\hline Mean: $171.5 \mathrm{~cm}$
\end{tabular}

